\title{
Prophets without honour?
}

\author{
Or honour without profits?
}

\section{R. M. Simmons}

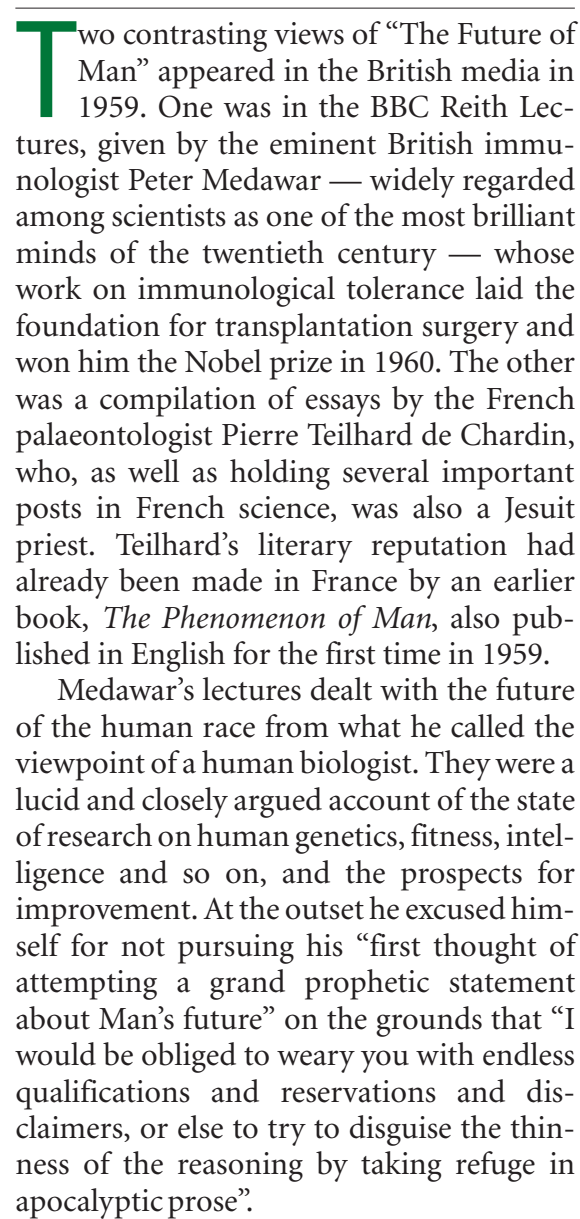

Teilhard had no such inhibitions: his view was that humans stood at the focal point of evolution, that there exists a kind of mental equivalent to the biosphere, the noosphere, which will eventually reach a critical point, analogous to self-consciousness. Sir Julian Huxley wrote an appreciative introduction for The Phenomenon of Man, and Arnold Toynbee wrote in the national newspaper The Observer: "This is a great book. Its subject is the sum of things; nothing less than God and the Universe. Teilhard sees and presents the Universe in evolution, but at the same time a unity. His vision of unity meets a spiritual need of our time."

Medawar begged to differ: in 1961 he launched an attack on The Phenomenon of Man - which by this time had become a semi-popular classic — in the journal Mind; an article subsequently anthologized and often quoted. He successfully demolished Teilhard's arguments in 11 pages of awesome, sustained invective. Or did he? Curiously, on close reading there is little real critical substance. He complains of Teilhard's

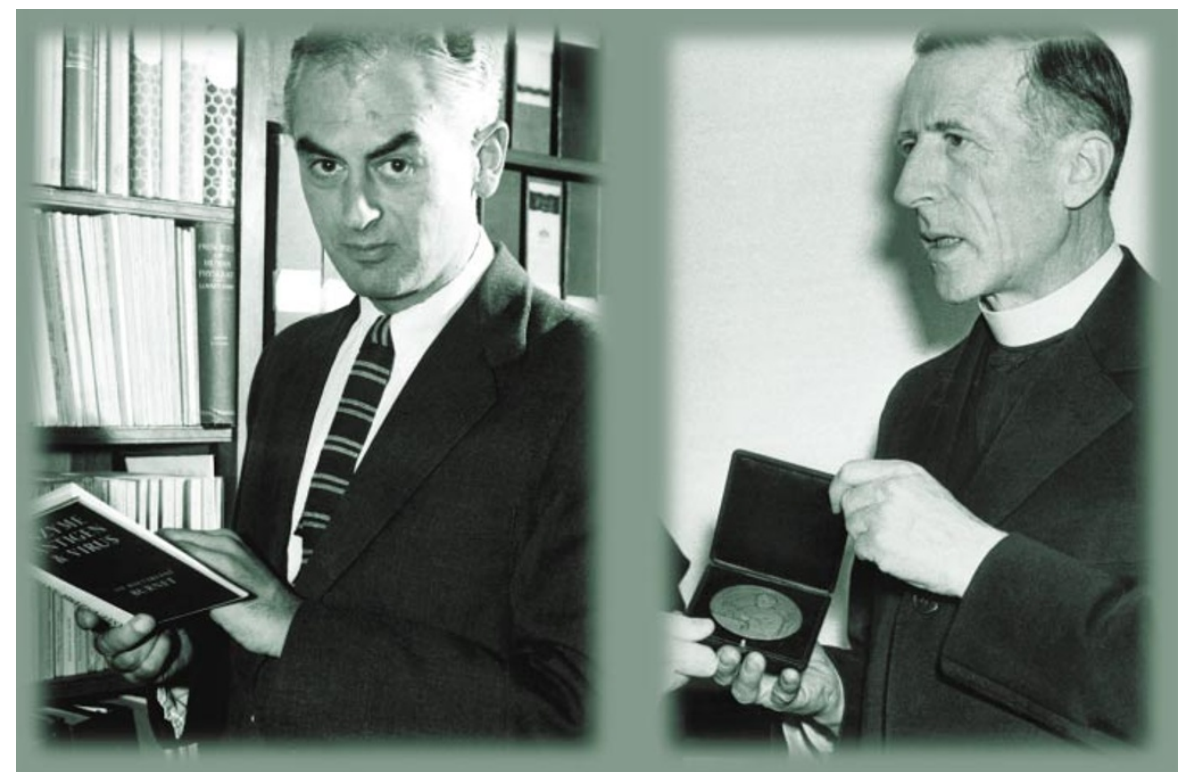

Spot the heretic: Medawar (left) took a dim view of the Jesuit Teilhard de Chardin's biology.

style ("tipsy prose-poetry"), some technical shortcomings ("no grasp of the real weakness of modern evolutionary theory"), but the main substantive issue is Teilhard's misappropriation of scientific arguments to promote a religious standpoint ("obscure pious rant") and so duping a gullible public ("educated far beyond their capacity to undertake analytical thought"). We shall never know what Teilhard thought of Medawar, as Teilhard died in 1954.

Teilhard's books were published posthumously: his religious superiors forbade him publishing his views on human evolution in his lifetime. He thus shared with Galileo the distinction, if that is the right word, of having his work suppressed by the Roman Catholic Church. Just because Galileo was right does not, of course, give everyone else whose work is proscribed the stamp of scientific rectitude, but Teilhard was doubly distinguished in his second martyrdom at the hands of scientific orthodoxy. But apart from its religious streak, Teilhard's approach is not so different from that of the

eilhard was doubly
distinguished in
falling foul of both the
Catholic Church and
scientific orthodoxy.

$\approx \odot 2000$ Macmillan Magazines Ltd modern field of evolutionary psychology, and he anticipated the explosive growth of mass communication. For a book written in the late 1930s, The Phenomenon of Man seems remarkably prescient.

Teilhard is not alone in being tried by the scientific establishment while experiencing popular success. A good deal of hostility has been directed at the concept of the biosphere as an intelligent organism - James Lovelock's Gaia - and at astronomer Fred Hoyle's ideas on the extraterrestrial origin of life. Both met with popular enthusiasm before the scientific establishment would admit that they were candidate hypotheses. The evolutionary biologist John Maynard Smith castigated Hoyle recently in this very journal (Nature 403, 594-595; 2000).

Teilhard's books must have far outsold Medawar's Reith Lectures, and therein lies a dilemma for scientists in their relationship with the public. Should they, like Medawar, stick to the facts, satisfying the dictates of scientific conscience but, with a limited horizon, reaching a limited audience? Or should they throw caution to the winds as Teilhard did, appeal to a large audience, but risk disapprobation by the scientific community? There is a psychological issue, too, which is that the public may have twigged that not only do orthodox scientists restrict their enquiries to the physical world, but also that many of them believe in their hearts that there is nothing beyond it.

R. M. Simmons is at the Randall Centre, King's College London, Guy's Campus, London SE1 1UL, UK. 